Original Article (Full paper)

\title{
Impact of primary hyperhidrosis on the life of physical education academics of a university in the Brazilian Northeast
}

\author{
Joana Julia Goes de $\operatorname{Campos}^{1} \oplus$, Maria Bernadete Galrão de Almeida Figueiredo ${ }^{2}$, Edna Santos $\operatorname{Dias}^{3} \oplus$, \\ Yasmim Anayr Costa Ferrari ${ }^{3}\left(\mathbb{D}\right.$, Sydney Correia Leão ${ }^{4}$, Renata Lima Batalha de Andrade $^{5}(\mathbb{D}$, Naiana Mota \\ Araujo $^{5}{ }^{(0}$, Maria Tainar Barbosa de Almeida ${ }^{5}$, , Maria Marta Prado Lima ${ }^{3}$, Sonia Oliveira Lima ${ }^{6}$ \\ ${ }^{1}$ Universidade Tiradentes, UNIT, Graduated in Medicine, Aracaju, SE, Brazil, ${ }^{2}$ Universidade Tiradentes, UNIT, \\ Master in Health and Environment, Professor, Aracaju, SE, Brazil, ${ }^{3}$ Universidade Tiradentes, UNIT, Graduate in \\ Nursing, Aracaju, SE, Brazil; ${ }^{4}$ Universidade Federal do Sao Francisco, UNIVASF, Graduated in Medicine, Specialist \\ in Pathology, Professor, Paulo Afonso, BA, Brazil, ${ }^{5}$ Universidade Tiradentes, UNIT, Undergraduate in Medicine, \\ Aracaju, SE, Brazil, ' ${ }^{6}$ niversidade Tiradentes, UNIT, PhD in Medicine, Professor, Aracaju, SE, Brazil
}

\begin{abstract}
Aim: To assess the prevalence, quality of life (QoL), and the damages caused by $\mathrm{PH}$, in the professional and personal scope of Physical Education academics with Primary Hyperhidrosis (PH). Methods: A descriptive, exploratory, qualitative and quantitative cross-sectional study was carried out. Twenty-five students from the physical education course at Tiradentes University, Aracaju-SE, were interviewed from August to November 2017. Validated questionnaires were used on PH's influence in academic activities and QoL. absolute and relative frequencies in the case of categorical variables and measures of trend and central variability in the case of numerical variables. Results: The prevalence of PH in students of Physical Education was $11.11 \%$, mainly in combined sites, such as palmoplantar, and with no difference between the sexes. The symptoms started mostly during childhood and adolescence. Most of the interviewees (92\%) reported difficulties with activities such as sports, use of personal protective equipment, handling of work equipment and instruments, and exacerbation in stress situations. They reported significant harm to QoL in situations of greeting people with handshakes, writing, wearing socks and dancing socially. Conclusion: Although PH is a disease that negatively impacts the QoL, it is still little known in the academic world with little demand for medical help. Therefore, it is necessary greater dissemination of the disease for its early diagnosis, related to the intensity of the sweating for a better therapeutic approach.
\end{abstract}

Keywords: sweat disease, quality of life, student health, disease impact profile.

\section{Introduction}

Throughout academic formation and within society, physical trainers (PT) are meant to be centered and to overcome the subject-object relation, and seen as healthy, self-determined people. These are features derived from the importance and value physical activity (PA) plays in health, competitiveness, stress control and aesthetics. Which not only stimulates interest but also pleasure in the performance of daily life activities ${ }^{1,2}$.

However, when PT suffer from a chronic disease such as primary hyperhidrosis, they may be stigmatized and feel unsafe whilst working due to excess sweating. Hyperhidrosis is defined as excessive sweating beyond the physiological needs of thermoregulation ${ }^{3}$. It is divided in primary if there is unknown etiology; or secondary, if it is caused by another disease. The main primary or focal hyperhidrosis anatomical sites are the hands, armpits, feet, and face ${ }^{4}$.

There are different prevalence ranges around the globe, ranging from $0.6 \%$ to $16.3 \%{ }^{5}$. In Brazil, the prevalence in the general population is $9.0 \%{ }^{6}$ and, in a specific group, $14.7 \%$. Sweating is usually bilateral, symmetrical, and triggered or worsened by stressful stimuli, with no interference from ambient temperature and usually ceases during sleep. It can range from mild local sweating to intense dripping, impacting the quality of life proportionally to disease severity ${ }^{8,9}$.

$\mathrm{PH}$ usually begins in childhood or adolescence and implies a significant negative impact on quality of life and is commonly associated with intense emotional, social and occupational stress $^{5,10}$. During infancy, PH bearers tend to be bullied by schoolmates because of the excessive sweating. The same situation is seen in the professional environment, having a direct impact in $\mathrm{QoL}^{11}$. $\mathrm{PH}$ diagnosis is clinical, with well-defined criteria and easy applicability ${ }^{6}$ and disease severity assessment is made using the Hyperhidrosis Disease Severity Scale (HDSS), which ranges from 1 to 4 , with grades 1 and 2 correspondings to mild or moderate hyperhidrosis, and grades 3 and 4 indicate severe hyperhidrosis ${ }^{12}$.

Overall knowledge about PH is still not adequate for such a prevalent disease $\mathrm{e}^{11,13}$. This condition is often undervalued and undernotified because of its low to unexistent impact in mortality ${ }^{11}$. Professional tasks such as handling work-related instruments, wearing uniforms and customer physical contact 
are hampered by excessive sweating, which interferes not only with the quality of life but also with PT professional service quality ${ }^{14,15}$. There is a need for better PH awareness within health professionals and the general population. This present work is a pioneer in the assessement of Primary Hyperhidrosis prevalence in Physical Education academics and in the assessment of their QoL.

\section{Method}

\section{Experimental Design}

This is a descriptive, exploratory cross-sectional study with a random quantitative and qualitative approach directed at a sample of students from the Physical Education area of the Tiradentes University located in Aracaju - SE.

\section{Subjects}

Students enrolled in the Physical Education course, whose quantitative, until the first half of the year 2017, was 925 students.

\section{Sample selection}

The sample was calculated using the Pocock formula ${ }^{16}$ and a conservative prevalence of $50 \%$, a $5 \%$ margin of error and a $95 \%$ confidence interval was estimated for size determination. Therefore, the sample number was 272 Physical Education academics. The sample period, collected for convenience, occurred from February to May 2018. The inclusion criteria were regularly enrolled academics in the undergraduate course in Physical Education of Tiradentes University, over 18 years old and who signed the Free and Informed Consent Term (TCLE). Exclusion criteria were individuals who were on school leave at the dates of application of the questionnaires, those who filled out the forms incorrectly in order to compromise the evaluation of the research, and those with diseases causing secondary hyperhidrosis.

\section{Data collection instrument}

The study utilised the interview method with three validated formularies. The Diagnostic Questionnaire ${ }^{6}$ is designed to be positive for $\mathrm{PH}$ in a case of excessive sweating for at least six months and at least two other disease-related properties. The PH Issues in Human Life Questionnaire ${ }^{17}$ is divided into 3 domains (functional-social, personal and emotional), and the score ranges from 20 to 100 , the higher the score the worse the quality of life. The last questionnaire focus on the impact on Academic and Extracurricular Activities. It evaluates academic knowledge about the disease, such as characteristics, limitations, constraints. All participants received information on every step of our research and signed an informed consent form.

\section{Ethical aspects}

The work was carried out in accordance with the guidelines and norms regulating research with human beings, and complies with Resolution No. 466, of December 12, 2012, of the National Health Council of the Ministry of Health - Brasília - DF. The research was approved by the Ethics and Research Committee, under protocol No. 2,474,593.

\section{Description of searched methods and variables}

The descriptive analysis was performed using absolute and relative frequencies, in the case of categorical variables, and by measures of trend and central variability in the case of numerical variables. All analyses were performed with IBM SPSS $^{\circledR}$ v20.0.

\section{Results}

Of the total population sample, 47 undergraduates were excluded, 23 were under 18 years of age, 14 refused to join the research, and 10 did not adequately fill the form. The total number of participants was $225(82.7 \%)$.

Of the students evaluated, 154 (68\%) were men and $71(32 \%)$ were women. In all, 25 students presented diagnostic criteria for $\mathrm{PH}$, with a prevalence of $11.11 \%$, of which $9(12.67 \%)$ were female and $16(10.38 \%)$ were male. According to the skin color reported by the interviewees, PH affected $15(60 \%)$ brown, 6 $(24 \%)$ whites, and $4(16 \%)$ blacks. The mean age was 22.72 years $(\mathrm{SD}=3.96)$ (Figure 1).

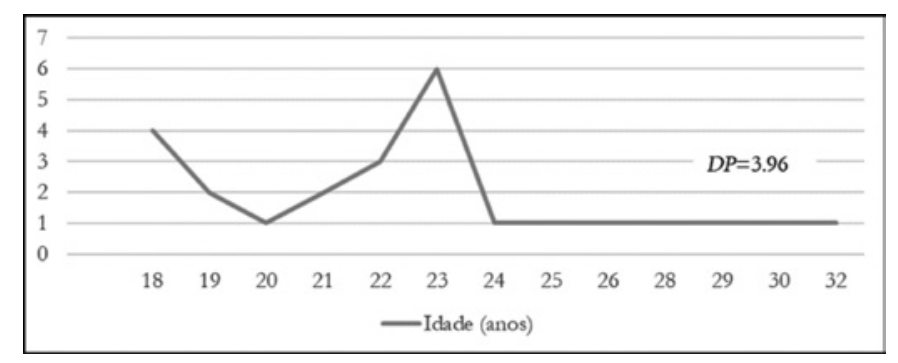

Figure 1: Variation of the age group of students with primary hyperhidrosis of the Physical Education course at a private university in Aracaju-SE, from August to November 2017.

Regarding the severity of PH by the HDSS scale, five (20\%) were grade 1 (imperceptible and never interfere with my daily activities), fifteen (60\%) grade 2 (tolerable, sometimes interfere with my daily activities), and five (20\%) grade 3 (unbearable, interferes frequently in my daily activities); which shows a prevalence of $\mathrm{PH}$ of $2.22 \%$ in grade $1,6.66 \%$ in grade 2 and $2.22 \%$ in grade 3 . There was no report of $\mathrm{PH}$ in grade 4 (intolerable, it always interferes with my activities daily).

The age at onset of $\mathrm{PH}$ symptoms was: 0 to 5 years $(4 \%), 5$ to 10 years $(12 \%), 10$ to 15 years $(32 \%), 15$ to 20 years $(28 \%)$, 20 to 25 years $(20 \%)$ and after 25 years $(4 \%)$. 
The affected anatomic sites were: axillary $68 \%$, plantar $56 \%$, palmar $52 \%$, craniofacial $28 \%$, back $8 \%$, buttocks $4 \%$, thighs $4 \%$ and inguinal region $4 \%$. The majority of the academics presented association in the palmar and plantar sites $5(20 \%)$; axillary and palmar 3 (12\%); axillary and plantar $1(4 \%)$; craniofacial and back $1(4 \%)$; axillary, palmar and plantar $2(8 \%)$; axillary, plantar and back 1 (4\%); axillary, plantar and craniofacial $3(12 \%)$; palmar, plantar and craniofacial $1(4 \%)$; axillary, palmar and buttocks 1 (4\%); axillary, palmar, plantar, craniofacial, thighs and inguinal $1(4 \%)$.

According to the diagnostic criteria of Felini, Demarchi, Fistarol, Matiello, Delorenze6(10) of the PH patients, 12 (48\%) reported bilateral and symmetrical sweating and $10(40 \%)$ had a frequency of one episode of excessive sweating per week. Sweat ceased during sleep in 7 (28\%) and had little temperature interference in $10(40 \%)$. Injury in daily activities was reported by $2(8 \%)$ of respondents, and $17(68 \%)$ reported worsening in stress situations. Positive family history was identified in 3 $(18 \%)$ of the academics.

Excessive sweating is considered an illness by $12(48 \%)$ of the interviewed students. In addition, none had undergone surgical treatment, and only $1(4 \%)$ sought clinical treatment using antiperspirant deodorants, aluminum hydroxide and homeopathy. The quality of life of $\mathrm{PH}$ patients was identified as very bad in $1(4 \%)$ academic, bad in $9(36 \%)$, good in $12(48 \%)$, very good in $3(12 \%)$ and there was no report of Excellent QdV Table 1.

Table 1: Hyperhidrosis Disease Severity Scale (HDSS) of 25 physical education students with primary hyperhidrosis at a private university in Aracaju-SE, from August to November 2017.

\begin{tabular}{lclccc}
\hline & Very bad & Bad & Good & Very Good & Excelent \\
\hline AF* $^{*}$ & 1 & 9 & 12 & 3 & 0 \\
HDSS grade (n) & $3(1)$ & $2(6)$ & $1(2)$ & $1(3)$ & 0 \\
& & $3(3)$ & $2(9)$ & & \\
& & & $3(1)$ & & \\
\hline
\end{tabular}

*AF: Absolute frequency

There were no reports of sharps injuries and $23(92 \%)$ of the students had difficulties with the work activities Tables 2 and 3.

Table 2: Distribution of work-related limitations related to PH's level, reported by the 25 academics with primary hyperhidrosis of the Physical Education course at a private university in Aracaju-SE, from August to November 2017.

\begin{tabular}{lcccc}
\hline & $\begin{array}{c}\text { Without } \\
\text { limitation }\end{array}$ & $\begin{array}{c}\text { Few } \\
\text { limitation }\end{array}$ & $\begin{array}{c}\text { Medium } \\
\text { limitation }\end{array}$ & $\begin{array}{c}\text { Great } \\
\text { limitation }\end{array}$ \\
\hline Written Evaluation & 14 & 6 & 3 & 2 \\
AF* & $1(5)$ & $2(5)$ & $2(2)$ & $2(1)$ \\
HDSS grade (n) & $2(7)$ & $3(1)$ & $3(1)$ & $3(1)$ \\
& $3(2)$ & & & \\
\hline Utilization of IPE**s & 13 & 8 & 4 & 0 \\
AF* $^{*}$ & $1(4)$ & $1(1)$ & $2(1)$ & \\
HDSS grade (n) & $2(8)$ & $2(6)$ & $3(3)$ & \\
& $3(1)$ & $3(1)$ & & \\
\hline
\end{tabular}

(To be continued)
Table 2: Distribution of work-related limitations related to PH's level, reported by the 25 academics with primary hyperhidrosis of the Physical Education course at a private university in Aracaju-SE, from August to November 2017.

\begin{tabular}{|c|c|c|c|c|}
\hline & $\begin{array}{l}\text { Without } \\
\text { limitation }\end{array}$ & $\begin{array}{c}\text { Few } \\
\text { limitation }\end{array}$ & $\begin{array}{c}\text { Medium } \\
\text { limitation }\end{array}$ & $\begin{array}{c}\text { Great } \\
\text { limitation }\end{array}$ \\
\hline $\begin{array}{l}\text { Performing of physical } \\
\text { examination }\end{array}$ & 9 & 11 & 4 & 1 \\
\hline $\mathrm{AF}^{*}$ & $1(2)$ & $1(2)$ & $2(1)$ & $1(1)$ \\
\hline \multirow[t]{2}{*}{ HDSS grade (n) } & $2(7)$ & $2(7)$ & $3(3)$ & \\
\hline & & $3(2)$ & & \\
\hline $\begin{array}{l}\text { Registration in } \\
\text { medical records }\end{array}$ & 13 & 7 & 3 & 2 \\
\hline $\mathrm{AF}^{*}$ & $1(4)$ & $2(4)$ & $2(3)$ & $1(1)$ \\
\hline \multirow[t]{2}{*}{ HDSS grade (n) } & $2(8)$ & $3(3)$ & & $3(1)$ \\
\hline & $3(1)$ & & & \\
\hline Handling equipment & 8 & 8 & 8 & 1 \\
\hline $\mathrm{AF}^{*}$ & $1(3)$ & $2(6)$ & $1(2)$ & $3(1)$ \\
\hline \multirow[t]{2}{*}{ HDSS grade (n) } & $2(5)$ & $3(2)$ & $2(4)$ & \\
\hline & & & $3(2)$ & \\
\hline Practice of sport & 10 & 11 & 3 & 1 \\
\hline $\mathrm{AF}^{*}$ & $1(3)$ & $1(2)$ & $2(2)$ & $2(1)$ \\
\hline \multirow[t]{2}{*}{ HDSS grade (n) } & $2(6)$ & $2(6)$ & $3(1)$ & \\
\hline & $3(1)$ & $3(3)$ & & \\
\hline Cut tape or micropore & 15 & 6 & 1 & 3 \\
\hline $\mathrm{AF}^{*}$ & $1(4)$ & $1(1)$ & $2(1)$ & $2(3)$ \\
\hline \multirow[t]{2}{*}{ HDSS grade (n) } & $2(9)$ & $2(2)$ & & \\
\hline & $3(2)$ & $3(3)$ & & \\
\hline $\begin{array}{l}\text { Comunication with the } \\
\text { patient }\end{array}$ & 17 & 5 & 3 & 0 \\
\hline $\mathrm{AF}^{*}$ & $1(4)$ & $2(4)$ & $1(1)$ & \\
\hline \multirow[t]{2}{*}{ HDSS grade (n) } & $2(10)$ & $3(1)$ & $2(1)$ & \\
\hline & $3(3)$ & & $3(1)$ & \\
\hline $\begin{array}{l}\text { Removing shoes in } \\
\text { public }\end{array}$ & 11 & 3 & 8 & 3 \\
\hline $\mathrm{AF}^{*}$ & $1(3)$ & $2(2)$ & $1(1)$ & $1(1)$ \\
\hline \multirow[t]{2}{*}{ HDSS grade (n) } & $2(6)$ & $3(1)$ & $2(5)$ & $2(2)$ \\
\hline & $3(2)$ & & $3(2)$ & \\
\hline
\end{tabular}

*FA: Frequência absoluta

**IPE: Individual Protection Equipment

Table 3: Analysis of the limitations in work activities reported by the 25 academics with primary hyperhidrosis of the Physical Education course at a private university in Aracaju-SE, from August to November 2017 .

\begin{tabular}{lc}
\hline \multicolumn{1}{c}{ Working activity } & Mean \pm SD (Interval) \\
\hline Written Evaluation & $0.72 \pm 0.979(0-3)$ \\
Utilization of IPE**s & $0.64 \pm 0.757(0-2)$ \\
Performing of physical examination & $0.88 \pm 0.832(0-3)$ \\
Registration in medical records & $0.76 \pm 0.969(0-3)$ \\
Handling equipment & $1.08 \pm 0.909(0-3)$ \\
Practice of sport & $0.8 \pm 0.816(0-3)$ \\
Cut tape or micropore & $0.68 \pm 1.029(0-3)$ \\
Comunication with the patient & $0.44 \pm 0.711(0-2)$ \\
Removing shoes in public & $1.12 \pm 1.129(0-3)$ \\
\hline
\end{tabular}


To minimize the limitations caused by PH, six (24\%) academics reported using some type of non-clinical strategy, such as antiperspirant deodorants $1(4 \%)$, more frequent change of clothes $1(4 \%)$, light and sweat absorbing $4(16 \%)$, use of tissues $1(4 \%)$ and avoid raising the arms $1(4 \%)$.

Constraints on touching the client were reported by $8(61.5 \%)$ academics who had palmar hyperhidrosis. In addition, thirteen (76.4\%) of patients with axillary hyperhidrosis reported a constraint on the use of academic clothing. A total of 8 (32\%) individuals had impairments in interpersonal relationships with multiprofessional staff and / or other academics, and 1 (4\%) reported embarrassment when using electronic devices.

Anxious situations such as tests, presentations of work in public, competitions and decision making, caused the emergence or increase of sweating in $19(76 \%)$ academics.

In the evaluation of the quality of life in relation to functionalsocial domains, the following results were found (Table 4):

Table 4: Distribution of the functional-social domain of the 25 Physical Education students with primary hyperhidrosis of a private university of Aracaju-SE, from August to November 2017, according to the classification of the quality of life questionnaire $(25,24)$

\begin{tabular}{lcclll}
\hline & \multicolumn{5}{c}{ Functional-social domain } \\
\cline { 2 - 6 } & Excelent & Good & Regular & Bad & Too bad \\
\hline Favorite Hobby & 5 & 11 & 1 & 3 & 5 \\
AF* & $1(2)$ & $1(1)$ & $1(1)$ & $2(3)$ & $1(1)$ \\
HDSS grade (n) & $2(3)$ & $2(7)$ & & & $2(2)$ \\
& & $3(3)$ & & & $3(2)$ \\
\hline To Practice sports & 5 & 11 & 3 & 2 & 4 \\
AF* & $1(3)$ & $1(1)$ & $1(1)$ & $2(2)$ & $2(2)$ \\
HDSS grade (n) & $2(2)$ & $2(8)$ & $2(1)$ & & $3(2)$ \\
& & $3(2)$ & $3(1)$ & & \\
\hline To be with friends & 4 & 11 & 6 & 3 & 1 \\
AF* & $1(2)$ & $2(9)$ & $1(1)$ & $1(1)$ & $1(1)$ \\
HDSS grade (n) & $2(2)$ & $3(2)$ & $2(2)$ & $2(2)$ & \\
& & & $3(3)$ & & \\
\hline To Dance socially & 3 & 6 & 10 & 4 & 2 \\
AF* & $1(1)$ & $2(5)$ & $1(3)$ & $2(2)$ & $1(1)$ \\
HDSS grade (n) & $2(2)$ & $3(1)$ & $2(5)$ & $3(2)$ & $2(1)$ \\
& & & $3(2)$ & & \\
\hline To wear sandals & 8 & 5 & 3 & 2 & 7 \\
AF* & $1(1)$ & $1(1)$ & $1(1)$ & $2(2)$ & $1(2)$ \\
HDSS grade (n) & $2(5)$ & $2(2)$ & $2(2)$ & & $2(4)$ \\
& $3(2)$ & $3(2)$ & & & $3(1)$ \\
\hline To wear socks & 7 & 5 & 2 & 5 & 6 \\
AF* & $1(1)$ & $1(1)$ & $2(1)$ & $1(2)$ & $1(1)$ \\
HDSS grade (n) & $2(5)$ & $2(2)$ & $3(1)$ & $2(3)$ & $2(4)$ \\
& $3(1)$ & $3(2)$ & & & $3(1)$ \\
\hline Handwork & 3 & 7 & 6 & 6 & 3 \\
AF* & $1(1)$ & $1(3)$ & $2(4)$ & $1(1)$ & $2(2)$ \\
HDSS grade (n) & $2(2)$ & $2(3)$ & $3(2)$ & $2(4)$ & $3(1)$ \\
& & $3(1)$ & & & $3(1)$ \\
\hline To write & 11 & 3 & 2 & 3 & 6 \\
AF* & $2(4)$ & $2(2)$ & $2(1)$ & $2(2)$ & $1(1)$ \\
HDSS grade (n) & $3(6)$ & & & $3(1)$ & $2(4)$ \\
\hline
\end{tabular}

(To be continued)
Table 4: Distribution of the functional-social domain of the 25 Physical Education students with primary hyperhidrosis of a private university of Aracaju-SE, from August to November 2017, according to the classification of the quality of life questionnaire $(25,24)$

\begin{tabular}{llllll}
\hline & \multicolumn{5}{c}{ Functional-social domain } \\
\cline { 2 - 6 } & Excelent & Good & Regular & Bad & Too bad \\
\hline Paste Objects & 9 & 6 & 3 & 5 & 2 \\
AF* & $1(2)$ & $1(1)$ & $1(1)$ & $1(1)$ & $2(1)$ \\
HDSS grade (n) & $2(6)$ & $2(3)$ & $2(2)$ & $2(3)$ & $3(1)$ \\
& $3(1)$ & $3(2)$ & & $3(1)$ & \\
\hline Shake hands & 6 & 6 & 3 & 4 & 6 \\
AF* & $1(1)$ & $1(1)$ & $2(3)$ & $1(2)$ & $1(1)$ \\
HDSS grade (n) & $2(4)$ & $2(4)$ & & $2(1)$ & $2(3)$ \\
& $3(1)$ & $3(1)$ & & $3(1)$ & $3(2)$ \\
\hline
\end{tabular}

*AF: Absolute frequency

Regarding the quality of life in the personal domain, the results described in table 5 were evidenced:

Table 5: Distribution of the personal domain of the 25 Physical Education students with primary hyperhidrosis from a private university in Aracaju-SE, from August to November 2017, according to the classification of the quality of life questionnaire. (25.24)

\begin{tabular}{lccccc}
\hline & \multicolumn{5}{c}{ Personal Domain } \\
\cline { 2 - 6 } & Excelent & Good & Regular & Bad & Too bad \\
\hline Intimate touch & 6 & 9 & 6 & 1 & 3 \\
AF* & $1(2)$ & $1(1)$ & $1(2)$ & $2(1)$ & $2(3)$ \\
HDSS grade (n) & $2(2)$ & $2(5)$ & $2(4)$ & & \\
& $3(2)$ & $3(3)$ & & & \\
\hline
\end{tabular}

*AF: Absolute frequency

Regarding the interference of $\mathrm{PH}$ in the emotional domainrelated quality of life, the following results were evidenced (Table 6):

Table 6: Distribution of the emotional domain of the 25 Physical Education students with primary hyperhidrosis from a private university in Aracaju-SE, from August to November 2017, according to the classification of the quality of life questionnaire $(25,24)$

\begin{tabular}{lcllll}
\hline & \multicolumn{5}{c}{ Personal domain } \\
\cline { 2 - 6 } & Excelent & Good & Regular & Bad & $\begin{array}{c}\text { Very } \\
\text { Bad }\end{array}$ \\
\hline $\begin{array}{l}\text { Needed to justify } \\
\text { AF* }\end{array}$ & $1(1)$ & $2(4)$ & $2(4)$ & $1(1)$ & $1(3)$ \\
HDSS grade (n) & $2(1)$ & $3(1)$ & $3(3)$ & $2(5)$ & $2(1)$ \\
& & & & $3(1)$ & \\
\hline It was observed & & 5 & 5 & 8 & 5 \\
demonstrations of & 2 & 5 & & & \\
rejection & $1(1)$ & $2(5)$ & $2(3)$ & $2(5)$ & $1(4)$ \\
AF* & $2(1)$ & & $3(2)$ & $3(3)$ & $2(1)$ \\
HDSS grade (n) & 2 & 5 & 7 & 7 & 4 \\
Needed to justify & $1(1)$ & $2(4)$ & $2(4)$ & $1(1)$ & $1(3)$ \\
AF* & $2(1)$ & $3(1)$ & $3(3)$ & $2(5)$ & $2(1)$ \\
HDSS grade (n) & & & & $3(1)$ & \\
& & & &
\end{tabular}

(To be continued) 
Table 6: Distribution of the emotional domain of the 25 Physical Education students with primary hyperhidrosis from a private university in Aracaju-SE, from August to November 2017, according to the classification of the quality of life questionnaire $(25,24)$

\begin{tabular}{llllll}
\hline & \multicolumn{5}{c}{ Personal domain } \\
\cline { 2 - 6 } & Excelent & Good & Regular & Bad & $\begin{array}{l}\text { Very } \\
\text { Bad }\end{array}$ \\
\hline $\begin{array}{l}\text { It was observed } \\
\text { demonstrations of } \\
\text { rejection }\end{array}$ & 2 & 5 & 5 & 8 & 5 \\
AF* & $1(1)$ & $2(5)$ & $2(3)$ & $2(5)$ & $1(4)$ \\
HDSS grade (n) & $2(1)$ & & $3(2)$ & $3(3)$ & $2(1)$ \\
\hline $\begin{array}{l}\text { Had the desire to } \\
\text { leave the place }\end{array}$ & 3 & 6 & 6 & 2 & 8 \\
AF* & $1(2)$ & $2(6)$ & $2(4)$ & $1(1)$ & $1(2)$ \\
HDSS grade (n) & $2(1)$ & & $3(2)$ & $3(1)$ & $2(4)$ \\
& 2 & 7 & 3 & 6 & 7 \\
\hline $\begin{array}{l}\text { Tried to stay away } \\
\text { from other people }\end{array}$ & $1(1)$ & $2(6)$ & $1(1)$ & $1(1)$ & $1(2)$ \\
AF* & $2(1)$ & $3(1)$ & $2(2)$ & $2(2)$ & $2(4)$ \\
HDSS grade (n) & & & & $3(3)$ & $3(1)$ \\
\hline
\end{tabular}

*FA: Absolute Frequency

Table 7 and 8 describe the results regarding quality of life assessment in relation to the special conditions.

Table 7: Domain distribution Special conditions of the 25 Physical Education students with primary hyperhidrosis of a private university of Aracaju-SE, from August to November 2017, according to the classification of the quality of life questionnaire. (25.24)

\begin{tabular}{lllllc}
\hline & \multicolumn{5}{c}{ Special Conditions } \\
\cline { 2 - 6 } & Excelent & Good & Regular & Bad & Very Bad \\
\hline Indoors & 5 & 3 & 6 & 4 & 7 \\
AF* & $1(3)$ & $1(1)$ & $2(6)$ & $1(1)$ & $2(3)$ \\
HDSS grade (n) & $2(2)$ & $2(1)$ & & $2(3)$ & $3(4)$ \\
& & $3(1)$ & & & \\
\hline In hot environments & 3 & 3 & 6 & 3 & 10 \\
AF* & $1(1)$ & $1(1)$ & $1(2)$ & $2(3)$ & $1(1)$ \\
HDSS grade (n) & $2(1)$ & $2(2)$ & $2(4)$ & & $2(5)$ \\
& $3(1)$ & & & & $3(4)$ \\
\hline Tense or worried & 2 & 3 & 7 & 3 & 10 \\
AF* & $1(1)$ & $1(2)$ & $1(1)$ & $2(3)$ & $1(1)$ \\
HDSS grade (n) & $2(1)$ & $3(1)$ & $2(5)$ & & $2(6)$ \\
& & & $3(1)$ & & $3(3)$ \\
\hline Thinking about it & 2 & 4 & 6 & 5 & 8 \\
AF* & $1(1)$ & $1(1)$ & $1(1)$ & $1(2)$ & $2(5)$ \\
HDSS grade (n) & $2(1)$ & $2(3)$ & $2(3)$ & $2(3)$ & $3(3)$ \\
& & & $3(2)$ & & \\
\hline With problems on & 3 & 4 & 4 & 6 & 8 \\
faculty & $1(3)$ & $2(4)$ & $2(2)$ & $2(5)$ & $1(2)$ \\
AF* & & & $3(2)$ & $3(1)$ & $2(4)$ \\
HDSS grade (n) & & & & & $3(2)$ \\
\hline
\end{tabular}

(To be continued)
Table 7: Domain distribution Special conditions of the 25 Physical Education students with primary hyperhidrosis of a private university of Aracaju-SE, from August to November 2017, according to the classification of the quality of life questionnaire. (25.24)

\begin{tabular}{llllll}
\hline & \multicolumn{5}{c}{ Special Conditions } \\
\cline { 2 - 6 } & Excelent & Good & Regular & Bad & Very Bad \\
\hline $\begin{array}{l}\text { Wearing coloured } \\
\text { clothes }\end{array}$ & 3 & 5 & 3 & 8 & 6 \\
AF* & $1(2)$ & $1(1)$ & $2(3)$ & $1(2)$ & $2(3)$ \\
HDSS grade (n) & $2(1)$ & $2(3)$ & & $2(5)$ & $3(3)$ \\
& & $3(1)$ & & $3(1)$ & \\
\hline Before Testing & 2 & 4 & 4 & 6 & 9 \\
AF* & $1(2)$ & $2(3)$ & $1(1)$ & $1(1)$ & $1(1)$ \\
HDSS grade (n) & $3(1)$ & $2(2)$ & $2(4)$ & $2(6)$ & \\
& & & $3(1)$ & $3(1)$ & $3(2)$ \\
\hline Prior to public & 2 & 3 & 6 & 3 & 11 \\
presentations & $1(1)$ & $2(2)$ & $1(3)$ & $2(2)$ & $1(1)$ \\
AF* & $3(1)$ & $3(1)$ & $2(3)$ & $3(1)$ & $2(8)$ \\
HDSS grade (n) & & & & & $3(2)$ \\
\hline
\end{tabular}

*AF: Absolute frequency

Table 8: Quality of life analysis in the functional-social, personal and emotional domains and in special conditions of the 25 Physical Education students with primary hyperhidrosis of a private university of Aracaju-SE, from August to November 2017, according to the classification of the quality of life questionnaire ${ }^{24,25}$.

\begin{tabular}{lc}
\hline \multicolumn{1}{c}{ Question } & Mean \pm SD (Interval) \\
\hline Functional-social domain & $2.32 \pm 1.464(0-4)$ \\
Favorite hobby? & $2.44 \pm 1.356(0-4)$ \\
Practice sports & $2.58 \pm 1.044(0-4)$ \\
To be with friends & $2.16 \pm 1.106(0-4)$ \\
To dance socially & $2.2 \pm 1.658(0-4)$ \\
To wear sandals & $2.08 \pm 1.605(0-4)$ \\
To wear socks & $2.04 \pm 1.241(0-4)$ \\
Handwork & $2.4 \pm 1.707(0-4)$ \\
To write & $2.6 \pm 1.384(0-4)$ \\
To paste objects & $2.08 \pm 1.552(0-4)$ \\
Shake hands & \\
\hline Personal domain & $2.56 \pm 1.261(0-4)$ \\
Intimate touch & \\
\hline Emotional Domain & $1.76 \pm 1.2(0-4)$ \\
Needed to justify & $1.64 \pm 1.254(0-4)$ \\
Observed demonstrations of rejection & $1.76 \pm 1.454(0-4)$ \\
Had the desire to leave the place & $1.64 \pm 1.38(0-4)$ \\
Tried to stay away from other people & \\
\hline Special Conditions & $1.8 \pm 1.5(0-4)$ \\
Indoors & $1.44 \pm 1.445(0-4)$ \\
In hot environments & $1.36 \pm 1.35(0-4)$ \\
Tense or worried & $1.48 \pm 1.326(0-4)$ \\
Thinking about it & $1.52 \pm 1.417(0-4)$ \\
With problems in faculty & $1.64 \pm 1.38(0-4)$ \\
Wearing colorful clothes & $1.36 \pm 1.35(0-4)$ \\
Before Test & $1.28 \pm 1.369(0-4)$ \\
Prior to public presentations & \\
\hline & \\
&
\end{tabular}




\section{Discussion}

The present study found a $\mathrm{PH}$ prevalence similar to previous studies such as Felini, Demarchi, Fistarol, Matiello, Delorenze $^{6}$ were $9 \%$ of individuals interviewed at bus stops had PH, in the city of Blumenau in Brazil; Westphal, Carvalho, Lima, Carvalho, Padilla, Araujo ${ }^{18}$ observed 5.5\% in medical students in the Amazonian capital; Augustin, Radtke, Herberger, Kornek, Heigel, Schaefer ${ }^{19}$ verified $16.6 \%$ in employees of companies in Germany; Fujimoto, Kawahara, Yokozeki ${ }^{20}$, with $12.7 \%$ in company employees and school students in Japan; Stefaniak, Tomaszewski, Proczko-Markuszewska, Idestal, Royton, Abi-khali121, with $16.7 \%$ in medical students in Poland; Lima, Aragão, Neto Machado, Almeida, Menezes, Santana ${ }^{7}$, with $14.7 \%$, also in medical students, in the state of Sergipe in Brazil. In older publications, prevalences such as Adar, Kurchin, Zweig, Mozes $^{22}$ with $1 \%$ in Israel; Strutton, Kowalski, Glaser, Stang ${ }^{23}$ with $2.8 \%$ in the USA; Tu, Li, Lin, Fran-cai, Li, Chen ${ }^{24}$ with $4.5 \%$ in China. The increase in PH prevalence observed in current research can be explained by better knowledge and investigation of the disease, by different methodologies of studies and / or regional aspects. In addition to the possibility of evaluating patients with different degrees of $\mathrm{PH}$.

In the present study, more men were interviewed, because the population studied was predominantly male. Because there was a greater male quantity, in the studied group, the proportion of the affirmative of $\mathrm{PH}$ was made according to sex. $\mathrm{PH}$ prevalence in physical education academics had no significant differences between genders, in agreement with literature where $\mathrm{PH}$ prevalence had a similar statistic in both genders ${ }^{24,25,26}$.

The sample exhibited a mean age of patients and symptom onset age similar to those found by other studies. Tu, $\mathrm{Li}$, Lin, Fran-cai, Li, Chen ${ }^{24}$ found $\mathrm{PH}$ patients with a mean age of 17.6 years, Park, Han, Choi, Kim, Kim $^{27} 28.5$ years, Fioreli et al. ${ }^{28} 25.4$ years, Delaplace et al. ${ }^{29} 29.3$ years. Strutton, Kowalski, Glaser, Stang ${ }^{23}$ described a mean age of patients with PH of 39.8 years. According to Moraites, Vaughn, Hill ${ }^{26}$, PH symptoms usually begin between 14 and 25 years of age. Tu, Li, Lin, Francai, $\mathrm{Li}, \mathrm{Chen}^{24}$ reported onset of clinical manifestations aged 4 to 22 years, with a peak between 6 and 16 years. Strutton, Kowalski, Glaser, Stang ${ }^{23}$ found the mean age of symptom onset of 25 years. PH, therefore, begins mainly in childhood and adolescence, times of transition and personality formation, recreational activities and social relations. This indicates the need for early diagnosis and treatment to reduce the negative impact of this disease on the quality of life of patients.

Ethnicity data is similar to those found in other studies, which demonstrate a lower prevalence within the black population ${ }^{8,30,31}$. There is a paucity of studies that assess the prevalence of ethnicity among patients with this condition, but probably the black ethnicity is the least affected.

Positive family history was found in the study and also evidenced in $15.3 \%$ in the study of Tu, Li, Lin, Fran-cai, Li, $\mathrm{Chen}^{24}, 65 \%$ of respondents in the Bellet study ${ }^{32}$ and $40.6 \%$ in the study by Alfy, Mowafy, Roshdy, Saad ${ }^{33}$. These findings suggest that family history is a relevant risk factor for $\mathrm{PH}$.
The most affected anatomic sites had prevalence similar to Estevan, Wolosker, Wolosker, Puech-Leão ${ }^{5}$, were the palmar site was the most affected site (48\%), followed by the axillary site (36.4\%). Visible body areas, which may lead to poor hygiene or nervousness interpretations.

Site association was in agreement with Bragança, Lima, Pinto Neto, Marques, Melo, Reis ${ }^{34}$, who observed $78.1 \%$ of patients with hyperhidrosis at more than one site. Park, Han, Choi, Kim, $\mathrm{Kim}^{27}$ detected a prevalence of palmoplantar hyperhidrosis of $32.2 \%$, and axillary-palmoplantar of $22.4 \%$, Estevan, Wolosker, Wolosker, Puech-Leão ${ }^{5}$ showed $62 \%$ of palmoplantar PH. Walling, Swick ${ }^{35}$ had the axillary site isolated as the most prevalent in its study with $29 \%$, followed by palmoplantar association $25 \%$, palmar isolated $15.5 \%$, axillarypalmoplantar $11 \%$, palmar $6 \%$, craniofacial $5 \%$, trunk $3 \%$, fold inguinal $1.3 \%$. In the areas of buttocks, legs, submammary, folds, neck and wrist the distributions were atypical, with less than $1 \%$ each. It is noted, therefore, that the sites most affected by $\mathrm{PH}$ are palmar, axillary and plantar. In addition, focal $\mathrm{PH}$ in isolated sites occurs in the minority of patients, being more common the association of two or more sites, which increases the embarrassment, and may hinder the activities of physical education academics.

Excessive sweating was considered a bad illness by all patients interviewed. None of the interviewees had undergone surgical treatment and only $4 \%$ sought clinical treatment. In the study by Augustin, Radtke, Herberger, Kornek, Heigel, Schaefer ${ }^{19}$, only $27 \%$ of $\mathrm{PH}$ patients consulted a physician because of their symptoms, and $28 \%$ used medication therapy. In reviewing the treatment of $\mathrm{PH}$, it was verified that only $38 \%$ of the patients seek care with the health professional because of this condition ${ }^{23,31}$. These data show that several sufferers live with the damages caused by excessive sweating, without even knowing that it is a disease and / or having treatment. Physical education academics are being empowered with motivational measures to exercise in the context in helping people in the preparation of a healthy life. Therefore, it is well known that early diagnosis and appropriate treatment are necessary to improve the QoL of these students.

The main diagnostic criteria reported by $\mathrm{PH}$ patients were worsening in situations of stress, bilateral and symmetrical sweating, frequency of one episode of excessive sweat per week, with little temperature interference. Regarding academic activities, most than half of the interviewees with palmar hyperhidrosis reported troubles when touching clients. Most patients reporting axillary hyperhidrosis felt embarrassed about the use of academic locker rooms, due to bodily odors (bromhidrosis).

Furthermore, anxiety seems to play a major role in excessive sweating cause and onset. Anxiety and stress evaluation is recurrent in the literature and Westphal, Carvalho, Lima, Carvalho, Padilla, Araujo ${ }^{18}$ found $5.5 \%$ of $\mathrm{PH}$ patients to have a negative interference in daily activities, whilst in Santana ${ }^{13}$, $30.6 \%$ reported some type of impairment in daily activities, and $76.5 \%$ presented worsening of sweating under stress. Studies have shown that individuals with $\mathrm{PH}$, especially in the axillary and facial sites, have a higher prevalence of anxiety in 
relation to the general population ${ }^{28,34,36,37}$. Physical education professionals have very close and intense contact with the recipients of their services and face physical and emotionalyl stressful situations during their chores ${ }^{2}$. It is noted, therefore, that excessive sweating when exacerbated by emotional stimuli leads to impairment in the daily activities of the physical education student.

Most of the interviewees also reported difficulties with activities such as sports, personal protective equipment (EPIS), handling of work equipment and instruments. Santan $a^{13}$ found that work activities lead to increased stress and, consequently, sweating, which generates more anxiety in the $\mathrm{PH}$ patient. The risk of accidents caused by excessive sweating in individuals with palmar $\mathrm{PH}$ is greater in professions that require the handling of instruments, which harms and disadvantages the patient with the disease. Professionals who need to maintain an interpersonal contact in their work become insecure and / or stressed in the practice of the work, which hinders the achievement and effectiveness of the academic activities of the physical trainer.

When it's used the Campos et al. ${ }^{17}$ questionnaire ${ }^{17}$, interviewees reported significant harm to QoL in situations of greeting people with handshakes, writing, wearing socks and dancing socially. The data found were similar to those of other studies, which demonstrated intense discomfort and low selfesteem in patients with $\mathrm{PH}$, besides a negative impact on QoL in social and professional settings ${ }^{7,35,38,39,40,41,42}$. $\mathrm{PH}$, although it is a chronic disease, beginning in the first decades of life, with significant prevalence and negative biopsychosocial interference, remains unknown by the general population and professionals of the health area. This fact demonstrates the need for scientific research to better understand the prevalence and consequences of $\mathrm{PH}$, as well as greater dissemination in academia.

None of the interviewees rated QoL in relation to hyperhidrosis as excellent. It can be inferred that the impact on QoL is directly proportional to the degree of $\mathrm{PH}$, since, in moderate degrees (HDSS 2 and 3), there is a significant impairment in the QoL of the patients.

\section{Conclusion}

The prevalence of primary hyperhidrosis in students of Physical Education at a private university in Aracaju-SE was $11.11 \%$. The disease occurred mainly in combined sites, such as palmoplantar, and with no difference between the sexes. The symptoms began mainly during childhood and adolescence, with significant impairment in daily personal and work activities, and exacerbation of sweat with stressful situations. Although primary hyperhidrosis is a disease that negatively impacts on the quality of life, especially in the most advanced degrees, is still little known in the academic world. Because of this, greater dissemination of the disease is necessary, as well as its early diagnosis and related to the intensity of sweating for a better therapeutic approach.

\section{References}

1. Koumantareas J, Oliveira, RCD. Sports and health from the perspective of physical education professionals. Motriz: J Phys Ed. 2018; 24 (4): e101870.

2. Guedes D, Gaspar E. "Burnout" em uma amostra de profissionais de Educação Física brasileiros. Rev Bras Educ Fís Esport. 2016; 30 (4): 999-1010.

3. Hashmonai M, Cameron AEP, Connery CP, Perin N, Lcht PB. The Etiology of Primary Hyperhidrosis: A Systematic Review. Clin Auton Res. 2017; 27 (6): 379-383.

4. Ohshima Y, Tamada, Y. Classification of Systemic and Localized Sweating Disorders. Curr Probl Dermatol. 2016; 51: 7-10.

5. Estevan F, Wolosker MB, Wolosker N, Puech-Leão P. Epidemiologic analysis of prevalence of the hyperhidrosis. An Bras Dermatol. 2017; 92 (5): 630-634.

6. Felini R, Demarchi AR, Fistarol ED, Matiello M, Delorenze LM. Prevalência de hiperidrose em uma amostra populacional de Blumenau - SC, Brasil. An Bras Dermatol. 2009; 84 (4): 361-366.

7. Lima SO, Aragão JFB, Neto Machado J, Almeida KBS, Menezes LMS, Santana VR. Research of primary hyperhidrosis in students of medicine of the State of Sergipe, Brazil. An Bras Dermatol. 2015; 90 (5): 661-665.

8. Lima SO, Abuawad YG, Santos PS, Pinto Neto AF, Santana VR, Reis FP. Infraareolar access for thoracoscopic sympathectomy to treat primary hyperhidrosis. Surg Today. 2013; 43 (2): 221-224.

9. Wolosker N, Campos JRM, Kauffman P, Oliveira LA, Munia MAS, Jatene FB. Evaluation of quality of life over time among 453 patients with hyperhidrosis submitted to endoscopic thoracic sympathectomy. J Vasc Surg. 2012; 55 (1): 154-156.

10. Grunfeld A, Murray CA, Solish N. Botulinum Toxin for Hyperhidrosis. Am J Clin Dermatol. 2009; 10 (2): 87-102.

11. Lima SO, Santana VR., Figueiredo MBGA, Fontes LM, Brito VAN, Andrade RLB. Gotinhas incômodas. Tem solução? Sebrae, 2016. 31 p.

12. Kowalski JW, Eadie N, Dagget S, Lai PY. Validity and reliability of the hyperhidrosis disease severity scale (HDSS). In: Paper presented at the 62nd annual meeting of the American Academy of Dermatology. Washington, DC, 6-10 February, 2004.

13. Santana VR. Prevalência de hiperidrose primária em grupos populacionais do estado de Sergipe, Brasil e avaliação da qualidade de vida antes e após simpatectomia lombar para o tratamento de hiperidrose plantar. Sergipe. Tese. [Doutorado em Saúde e Ambiente] - Universidade Tiradentes; 2017.

14. Benohanian A. L'hyperhidrose palmopantaire les cliniciens peuvent aussi la traiter. Le Clinicien. 2006; 81-84.

15. Lara ACC, Rossoe EWT. Tratamento cirúrgico da hiperidrose axilar: "Shaving" interno das glândulas sudoríparas. Surg Cosmet Dermatol. 2014; 6 (2): 175-177.

16. Pocock SJ. The size of a clinicaltrial. In: Pocock SJ. Clinical trials: a practical approach. Chinchester; New York: Wiley, 1983: 123-141.

17. Campos JRM, Kauffman P, Werebe EC, Filho LOA, Kuzniek S, Wolosker N, et al. Questionnaire of quality of life in patients with primary hyperhidrosis. J Bras Pneumol. 2003; 29 (4): 178-181. 
18. Westphal FL, Carvalho MAN, Lima LC, Carvalho BCN, Padilla R, Araujo KKL. Prevalência de hiperidrose entre estudantes de medicina. Rev Col Bras Cir. 2011; 38 (6): 392-397.

19. Augustin M, Radtke MA, Herberger K, Kornek T, Heigel H, Schaefer I. Prevalence and Disease Burden of Hyperhidrosis in the Adult Population. Dermatology. 2013; 227: 10-14.

20. Fujimoto T, Kawahara K, Yokozeki H. Epidemiological study and considerations of primary focal hyperhidrosis in Japan: From questionnaire analysis. J Dermatol. 2013; 40 (11): 886-890.

21. Stefaniak T, Tomaszewski KA, Proczko-Markuszewska M, Idestal A, Royton A, Abi-khalil C. Is subjective hyperhidrosis assessment sufficient enough? Prevalence of hyperhidrosis among young Polish adults. J Dermatol. 2013; 40: 819-823.

22. Adar R, Kurchin A, Zweig A, Mozes M. Palmar hyperhidrosis and its surgical treatment: A report of 100 cases. Ann Surg. 1977; 86 (1): 34-41.

23. Strutton DR, Kowalski JW, Glaser DA, Stang PE. US prevalence of hyperhidrosis and impact on individuals with axillary hyperhidrosis: Results from a national survey. J Am Acad Dermatol. 2004; 51 (2): 241-248.

24. Tu YR, Li X, Lin M, Fran-cai L, Li YP, Chen JF, et al. Epidemiological survey of primary palmar hyperhidrosis in adolescent in Fuzhou of People's Republic of China. Eur J Cardiothorac Surg. 2007; 31: 737-739.

25. Stori Jr WS, Coelho MS, Guimarães PSF, Neto NB, Pizarro LD. Bloqueio por clipagem de gânglios simpáticos torácicos no tratamento da hiperidrose. An Bras Dermatol. 2006; 81 (5): 425-432.

26. Moraites E, Vaughn OA, Hill S. Incidence and Prevalence of Hyperhidrosis. Clin Dermatol. 2014; 32 (4): 457-465.

27. Park EJ, Han KR, Choi H, Kim W, Kim C. An Epidemiological Study of Hyperhidrosis Patients Visiting the Ajou University Hospital Hyperhidrosis Center in Korea. J Korean Med Sci. 2010; 25 (5): 772-775.

28. Fiorelli RKA, Elliot LG, Alvarenga RMP, Morard MRS, Almeida CR, Fiorelli SKA, et al. Avaliação do Impacto na qualidade de Vida de Pacientes Portadores de Hiperidrose Primária Submetidos à Simpatectomia Videotoracoscópica. Meta: Avaliação. 2011; 3 (7): 1-24.

29. Delaplace M, Dumont P, Lorette G, Machet L, Lagier L, Maruani A, et al. Factors associated with long-term outcome of endoscopic thoracic sympathectomy for palmar hyperhidrosis: a questionnaire survey in a cohort of French patients. Br J Dermatol. 2015; 172 (3): 805-807.

30. Buraschi J. Videothoracoscopic sympathicolysis procedure for primary palmar hyperhidrosis in children and adolescents. Arch Argent Pediatr. 2008; 106 (1): 32-35.

31. Gelbard C, Epstein H, Hebert A. Palmar Pediatric Hyperhidrosis: A Review of Current Treatment Options. Pediatr Dermatol. 2008; 25 (6): 591-598.

32. Bellet JS. Diagnosis and Treatment of Primary Focal Hyperidrosis in Children and Adolescents. Semin Cutan Med Surg. 2010; 29 (2): 121-126.

33. Alfy EK, Mowafy K., Roshdy H, Saad E. Transthoracic Endoscopic Sympathetic Clipping for Hyperhidrosis and Facial Blushing. (Preliminary report). EJVES. 2011; 7 (1): 39-48.
34. Bragança GMG, Lima SO, Pinto Neto AF, Marques LM, Melo EV, Reis FP. Avaliação da prevalência de ansiedade e depressão em portadores de hiperidrose primária grave. An Bras Dermatol. 2014; 89 (2): 232-237.

35. Walling HW, Swick BL. Treatment options for hyperhidrosis. Am J Clin Dermatol. 2011; 12 (5): 285-95.

36. Lessa LR., Fontenelle LF. Toxina botulínica como tratamento para fobia social generalizada com hiperidrose. Rev Psiquiatr Clín. 2011; 38 (2): 84-86.

37. Benson RA, Palin R, Holt PJE. Diagnosis and management of hyperhidrosis. BMJ Journals. 2013; 347: f6800.

38. Montessi J, Almeida EP, Vieira JP. Simpatectomia torácica por videotoracoscopia para tratamento da hiperidrose primária: estudo retrospectivo de 521 casos comparando diferentes níveis de ablação. J Bras Pneumol. 2006; 33 (3): 248-254.

39. Vanderhelst E, Keukeleire S, Verbanck S, Vincken W, Noppen M. Quality of life and patient satisfaction after video-assisted thoracic sympathicolysis for essential hyperhidrosis: a follow-up of 138 patients. J Laparoendosc Adv Surg Tech A. 2011; 21 (10): 905-909.

40. Oliveira FRG. Análise morfométrica de neurônios de gânglios simpáticos torácicos de pacientes com e sem hiperidrose primária palmar. São Paulo.Tese. [Doutorado em Cirurgia Torácica e Cardiovascular]- Universidade de São Paulo, Faculdade de Medicina; 2013.

41. Henriques M, Costa J. Botulinum Toxin Type A Iontophoresis in Palmar Hyperhidrosis. Revista da SPMFR. 2014; 26 (2): 36-40.

42. Martin A, Hellhammer J, Hero T, Max H, Schult J, Terstegen L. Effective prevention of stress-induced sweating and axillary mal-odour formation in teenagers. Int J Cosmet Sci. 2011; 33 (1): 90-97.

43. Sampaio GAA, Almeida ART, Saliba AFN, Queiroz NPL. Hiperidrose infra mamária: caracterização clínica e gravimétrica. Surg Cosmet Dermatol. 2013; 5 (2): 146-149.

\section{Corresponding author}

Sonia Oliveira Lima

Beira Mar Avenue, Beverly Hills Condominium, no 1044, Ap. 602, 13 de Julho, Aracaju / SE, CEP 49020-010.

Email: sonialima.cirurgia@gmail.com

Manuscript received on January 22, 2019

Manuscript accepted on April 26, 2019

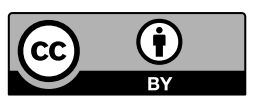

Motriz. The Journal of Physical Education. UNESP. Rio Claro, SP, Brazil - eISSN: 1980-6574 - under a license Creative Commons - Version 4.0 